\title{
Research On The Construction Path And Evaluation System Of "Ideological And Political Course" Of Management Specialty In Applied Colleges And Universities Under The Background Of Internet
}

\author{
Xiaoyun Duan ${ }^{1}$ Xiang $\mathrm{Gao}^{2}$ Shuchen Yang ${ }^{3 *}$ \\ 1,2,3 Jiangxi Tourism \& Commerce Vocational College, Nanchang, Jiangxi, 330000, China
}

\begin{abstract}
The rise of Internet technology brings opportunities for the development of various industries in China, and creates a good environment for the information construction and the innovation and cultivation of talents in colleges and universities. Although Internet technology has changed the traditional teaching thinking and mode, under the background of "Internet ", the openness of information, the diversity of culture and the contradiction between various trends of thought make students' moral understanding and ideas face severe challenges. The major of management is mainly to train professionals who meet the needs of market economy and adapt to the development of modernization. They should not only master the professional knowledge of economic management, but also have the ability and comprehensive accomplishment to engage in practical financial work. Therefore, the applied colleges and universities should take the Internet platform as the opportunity to explore the construction path and evaluation system of college students' ideology and morality, and create an environment for the healthy development of students.
\end{abstract}

\section{Introduction}

For a long time, the ideological and political work of colleges and universities has been studied and concerned by outside scholars. As an important means to adhere to the socialist direction of running a school, ideological and political education in colleges and universities plays an important role in ensuring the implementation of talent training programs and improving the quality of professional talents. As a new thought and method of ideological and political education, curriculum ideological and political education puts forward new requirements for the future ideological and political work in colleges and universities. Although colleges and universities are actively exploring the implementation of curriculum ideological and political programs, there is still no unified model. How to construct the teaching mode of curriculum ideological and political work and how to do well the evaluation system of ideological and political work has become an urgent problem in colleges and universities.

\section{The Theoretical Basis of Carrying out the Course of Ideological and Political Science in Applied Colleges and Universities}

At present, ideological and political curriculum is not a new curriculum, but a new teaching method and concept. The essence of curriculum thought and politics is to transfer the elements and connotations of thought and politics to students through the form of other courses. For example, the professional courses of management can transmit the essence and knowledge of ideological and political elements to students through typical cases, characters, stories and so on, which plays a subtle guiding role for students.

\subsection{Analysis of necessity}

1) The Needs of Students' Moral Development: At present, the moral situation of applied college students is characterized by obvious characteristics of the times, and students yearn for the realization of personal value while pursuing the mainstream values of society. However, with the reform of society and the application of Internet technology, ideology is in a completely open state, and various trends of thought, culture and values are mixed

\footnotetext{
*Corresponding author's e-mail: 739960103@qq.com
} 
among them. In this environment, college students' values, career outlook and employment outlook show complex and diversified characteristics[1]. In the face of the temptation of money, material, desire and so on, some college students have the dislocation of the concept of honor and disgrace and the view of right and wrong, which is manifested in weariness, abandonment of learning and quick success and instant benefit. Some college students take self-centeredness in thinking and behavior, pursue the maximization of individual interests and the realization of self-worth, and ignore the collective and public interests. Because college students are in the critical period of growth, autonomy, control ability, willpower and resolution ability are not mature, it is easy to be affected by external adverse effects and produce cognitive bias. According to the requirements of the Ministry of Education, students should realize the all-round development of morality, intelligence, body, beauty and labor during the school period[2]. The so-called "educating people first, moral education first" shows that the development of morality is very critical to the growth of students. The traditional "point" and "line" teaching obviously can not meet the needs of students' moral development, and the professional courses, as the main channels for students to learn, are easier to realize the internalization of knowledge and virtue through the organic integration with ideological and political education.

2) Business needs: Applied colleges and universities export a large number of management professionals to the society every year, they are often engaged in finance, trade, management, management and other industries. After graduation, students will directly enter the enterprise to engage in operational or grass-roots management positions, daily contact with the cash flow of the enterprise, project operation, business information and so on. Students are usually at the end of the management network of the enterprise and assume specific management functions and post responsibilities. Whether their professional ethics is healthy or not, whether their values are correct or not, and whether they innovative consciousness is cultivated or not will affect the further development of the enterprise. Therefore, under the background of ideological and political curriculum, teachers should not only guide students to master solid professional knowledge and ability, but also make students correctly understand industry norms, master relevant legal systems, clarify professional norms and form correct professional ethics norms.

3) Teaching needs: How to promote the mutual construction of curriculum ideological and political and professional system in applied colleges and universities is very helpful to the reform of curriculum ideological and political education and the development of management specialty itself. On the one hand, the educational idea of "people-oriented and moral education" advocated by the curriculum politics plays a positive role in guiding students to get rid of the tendency of imbalance, egoism and materialism, and finally urges students to form a sound personality. On the other hand, because the content of the course of management involves a wide range, the communication between teachers and students is more convenient under the background of Internet, which further expands the breadth and depth of ideological and political education[3].

\section{2 probability analysis}

The ideological and political teaching system of applied colleges and universities is based on the essential relationship between professional curriculum and ideological and political education. Because the goal of professional courses and ideological and political education is to cultivate applied, responsible and innovative talents for the society to meet the needs of economic development and financial posts. Therefore, the starting point and foothold of professional curriculum and ideological and political education are to realize the aim of people-oriented education. At the same time, the professional course is to cultivate students' professional skills, practical operation and professional understanding, so that students can firmly grasp the theoretical knowledge and skills of economic majors, and promote students to form the ability to understand, analyze and solve problems. Curriculum ideological and political education is to cultivate students' ideological and moral understanding and values from the ideological level, and finally make students form a value orientation in line with social norms. In this process, professional courses and ideological and political education are mutual penetration, mutual integration.

\section{The present situation and reasons of ideological and political teaching in the courses of economics and management}

At present, the dilemma of ideological and political teaching in the course of management is mainly manifested in the following two aspects:

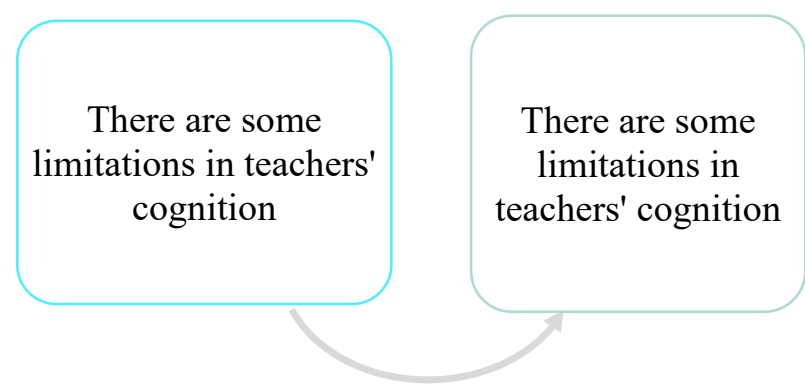

Figure 1. The dilemma of ideological and political teaching in the course of management

\subsection{There are some limitations in teachers' cognition}

1) The responsibilities of ideological and political subjects are unclear: Under the influence of solidified teaching division of labor and teacher role orientation, most professional teachers think that ideological and 
political education should be the responsibility of ideological and political teachers and related personnel in the management of academic workers. Professional teachers are only responsible for teaching students' professional knowledge and skills, but ignore the role of moral education in the classroom. Although the teaching requirements of ideological and political courses in some colleges and universities have become more and more clear, some teachers still regard ideological and political education as an additional function of the classroom and lack the consciousness of home.

2) The connotation of course politics is not clear: Professional teachers have two typical manifestations in ideological and political education. Some teachers will add some professional and theoretical ideological and political theories into the curriculum, so as to achieve the effect of ideological and political education. Some teachers think that every class should have ideological and political elements, so copy mechanically, the content is far-fetched and can not achieve educational results.

3) Students' trait mastery is not accurate: In order to achieve the expected teaching effect, teachers should first clearly grasp the characteristics and needs of students. However, in the actual teaching activities, teachers only according to the content of teaching materials and their own teaching experience, completely ignore the students' interest in learning, ways and ideological understanding level[4].

\subsection{Professional teachers' ideological and political literacy and ability need to be improved}

Professional teachers usually pay attention to the knowledge and latest developments of their major in their daily study and research, but pay little attention to ideological and political education. Although teachers can also understand the national policy and the spirit of major conferences in daily news, newspapers, lectures and studies, due to the lack of attention, the daily political information can not serve their own political level and ideological awareness. Therefore, it is also difficult for teachers to transform these political theories, ideas and conference spirit into ideological and political education resources.

\subsection{Lack of Moral Education}

According to the task of ideological and political education in colleges and universities, some professional teachers gradually carry out ideological and political education in the classroom. A teacher usually adopts a "teaching-oriented" way of moral education, and the teacher shows the PPT. to the students while dictating Because the self-consciousness of college students after 90 and 00 is very strong, it is obviously difficult to stimulate students' interest in learning.

\section{The Construction Path of "Ideological and Political Course" in the Management Specialty of Applied Colleges and Universities}

\subsection{To raise the importance of the course of thought and politics}

First of all, college managers should pay more attention to "curriculum ideological and political ", increase the investment of" curriculum ideological and political "project, and avoid the formalization and homogenization of project construction. Secondly, colleges and universities should cultivate teachers' political literacy, improve their ideological and political ideas, and encourage teachers to carry out education on students' traditional identity and choice ability. Finally, colleges and universities should set up special leading working groups and moral education supervision groups, give full play to the administrative functions of departments, and grasp the ideological and political direction of teachers and students in colleges and universities as a whole.

\subsection{To promote the two-way integration of ideological and political courses}

Ideological and political courses can provide students with professional ideological and political theory teaching, teachers can combine stories and cases to teach in the classroom, so as to improve the richness and interest of the classroom. In addition, the professional courses of management and management involve the experience and post knowledge of serial number industry, which provides a realistic environmental basis for ideological and political education, thus further research scope of ideological and political education. Therefore, there is an inevitable complementarity and cooperation between the curriculum and the ideological and political curriculum.

\subsection{Enhancing students' ability to introspect}

Although the Internet brings more resources and the possibility of development to the education of colleges and universities, it also has a certain impact on the consciousness and core values of college students. Therefore, in addition to ideological and moral education for students in the classroom, college teachers should also enhance students' self-learning, self-consciousness and self-regulation ability, so that college students have a basic judgment on external information and environment [5]. 


\section{Evaluation System of "Ideological and Political Course" for Management Specialty in Applied Colleges and Universities}

\subsection{Strictly set the entry threshold for university teachers}

At present, the selection of teachers in colleges and universities usually adopts the examination process of written examination interview, which mainly examines the teachers' professional knowledge, while the interview is to investigate the teachers' teaching skills. Obviously, teachers' ideological, moral and comprehensive literacy are not in the selection and employment standards of colleges and universities. If colleges and universities want to further promote the development of curriculum ideological and political, they must first have a group of teachers with excellent quality and high ideological and political concept, and the selection and employment work is to ensure the advanced nature of teachers' thought and the standardization of morality from the source. Therefore, the examination of ideological, moral and political quality should be added to the selection and employment of teachers in colleges and universities, and it should run through the overall management system and development plan of teachers. Therefore, colleges and universities should set up strict assessment standards from two aspects: professional skills and ideology and morality.

\subsection{Make clear the assessment index and standard of course thought and politics}

The assessment can be comprehensively evaluated from the perspective of teacher self-evaluation, teacher mutual evaluation, student evaluation, supervision score, college leadership score and so on. Colleges and universities should focus on the implementation effect of teachers' ideological and political teaching, such as teachers' participation in ideological and political projects and the display of ideological and political education skills. Colleges and universities should organize teaching evaluation activities every semester. Students should not only rate teachers' teaching preparation, content, skills, progress and results, but also evaluate teachers' dress, discipline and ethics, so as to urge teachers to maintain the image of people's teachers at all times.

In addition, the evaluation of students should also be integrated into the ideological and political assessment. For example, scholarship selection, because students should be comprehensive development, so scholarship assessment should not be "one-size-fits-all" approach. Because students' learning is a dynamic process, the average scores of the same academic year and the next two semesters should be taken into account in the aspect of achievement statistics as a measure of students' learning situation throughout the year. In addition to learning, college students also participate in various activities and deal with different students or teachers every day, so the comprehensive performance of students in school should also be included in the category of scholarship selection. The school can set up the learning attitude, the number of volunteer activities, the situation of helping others, the number of violations of discipline, absenteeism and other assessment indicators in the comprehensive evaluation, each index set the corresponding standards and weights. Quantitative evaluation results can truly reflect students' behavior and moral performance for one semester or the whole year.

\section{CONCLUSION}

In order to promote economic development and accelerate social reform, colleges and universities should combine ideological and political education with the curriculum teaching of economics and management to realize the development of students' knowledge, skills, morality and aesthetics.

\section{REFERENCES}

1. C, S.J. (2020) Teaching Design and Practice of "Ideological and Political Course" in Economic Law of Economic Management Specialty[J]. Journal of Wuhan Institute of Engineering Technology.

2. Li, H. (2020) A Study on the Path of Ideological and Political Education in Professional Curriculum from the Perspective of Ideological and Political - Taking Applied Economics and Management as an Example[J]. Education and Teaching Forum.

3. Du, F.F.(2019)A Study on the Way of Ideological and Political Implementation of Curriculum Based on Applied Talent Training Model - - Taking Management as an Example[J].Modernization of education.

4. She, Y.W. (2019) A Study on the Construction of Ideological and Political Teaching System in the Course of Economics and Management in Applied Undergraduate Colleges[J]. Yangtze River Series.

5. Wei, Q. Wu, Y. (2018) Ideological and political teaching of courses based on flipping classroom - taking applied undergraduate economics and management specialty as an example[J]. Cultural and educational materials. 